\title{
The Mystery of the GERD Negotiations: From Coercion to Obligation of Treaty Conclusion
}

\author{
DOI http://dx.doi.org/10.4314/mlr.v15i2.7
}

\section{Abstract}

Dejen Yemane Messele*

This comment examines the use of coercive power in the negotiations between Ethiopia, Egypt, and Sudan on the filling and annual operation of the Grand Ethiopian Renaissance Dam (GERD). There has been deliberate use of coercive power (the use of military, economic and political coercion) by Egypt, Sudan, and their geopolitical allies mainly since November 2019. Coupled with the use of coercion, the lower riparian negotiating parties perceive that concluding an agreement over the subject matter is a legal duty imposed on Ethiopia, not just a volitional dealing that could emanate from the spirit of cooperation and good faith. Careful interpretation of the international law regime unveils that all forms of coercion are unlawful despite the difference in the degree of illegality between military, economic and political coercion. The existence of coercion, in all its forms, would thus absolve Ethiopia's duty (if any) to conclude an agreement with the two downstream states. I argue that, Ethiopia -as victim of an unlawful coercion- has the right to withdraw from the GERD negotiations and to unilaterally proceed with the filling and operation of its sovereign dam while at the same time respecting the principles of equitable utilization and not causing significant harm which can be facilitated by a basin-wide water governance treaty rather than trilateral negotiation on a single dam project.

\section{Key terms}

Nile $\cdot$ GERD $\cdot$ GERD Negotiations $\cdot$ Coercion · Treaty conclusion · Hegemony

\section{Suggested citation:}

Dejen Yemane Messele (2021), 'The Mystery of the GERD Negotiations: From Coercion to Obligation of Treaty Conclusion', 15 Mizan Law Review 2: 523-542.

* Dejen Yemane Messele: LL,B, LL,M (International Law, AAU), PhD Candidate, AAU, School of Law; Lecturer@ Wollo University School of Law Email: dejen.yemane@aau.edu.et ORCID: https://orcid.org/0000-0003-4161-5485

The first draft version of this comment was presented before a national conference organized by Gondar University, School of Law on the theme: The GERD; International water law, Dispute resolution, and Sovereignty, 10-11 June 2021. 


\section{Contents}

Abstract

1. Introduction

2. The GERD Negotiations: From Unwarranted Encroachment to Coercion

3. Coercion as a Driving Force in the GERD Negotiations: Adducing Evidence

4. The Legal Contours of Coercion

5. The Duty to Conclude Treaty: With or Without Coercion

6. Concluding Remarks

\section{Introduction}

Despite the discursive narratives about the GERD negotiations and polarized polemics, a critical turn is badly needed to truly understand the what, why and how of the GERD negotiations proceeded. A critical augury can help to illuminate the details of the GERD politics. The flawed narratives behind the GERD and its negotiations calls for the need to look the Nile politics in general and the GERD negotiations in particular from critical vantage points.

The critical insight, as discussed in this comment, unveils that Egypt is exercising its unmediated power of coercion with no restraint. Egypt keenly uses international law as a hegemonic instrument ${ }^{1}$ under the guise of 'historic rights' by disregarding fundamental changes of circumstances (rebus sic stantibus) thereby downplaying the principle of equitable utilization which is among the core contemporary international principles of trans-boundary water resources.

\section{Frequently used acronyms}

$\begin{array}{ll}\text { GERD } & \text { Grand Ethiopian Renaissance Dam } \\ \text { ICJ } & \text { International Court of Justice } \\ \text { IPoE } & \text { International panel of experts } \\ \text { VCLT } & \text { Vienna Convention on the Law of Treaties }\end{array}$

${ }^{1}$ Egypt's use of international law as a tool for hydro-hegemony aims at economic and geo-political hegemony. Economic imperialism, hegemonic international law and coercive diplomacy have a symbiotic relationship. The policy of hegemony in international relations was condemned by the UN General Assembly, GA Resolution 34/103, UN Doc A/RES/34/103 (14 December 1979). 
Signing an agreement with Ethiopia relating to the filling and the operation of the GERD is a pretext and an instrumental handcuff so that Ethiopia becomes obliged to negotiate with upper riparian states rather than use its sovereign rights toward equitable utilization. Ethiopia's resistance, once outmaneuvered, to Egypt's move for the preservation of an unjust status quo is clogged through the coercion Egypt has exerted in the process. ${ }^{2}$

Egypt is invoking 'acquired rights' and 'current uses' over the Nile River, and it has been using colonial treaties to sustain its hegemony over Nile waters. ${ }^{3}$ The negotiation from Egypt's perspective is merely reluctance to accept fundamental change of circumstances in the need for equitable utilization by preserving its hegemonic control of the Nile waters. To this end, it is trying to instrumentalize negotiations and colonial treaties, and, in effect, legitimize its factual or actual hegemony over the River Nile. ${ }^{4}$

The next two sections of this comment discuss the (il)legality of subjection of the GERD for a trilateral negotiation. In this regard, military economic and political coercion are explored. Legality test is made (in Section 4) on each form of coercion in the eyes of international law. The fifth section discusses the duty of conclusion of treaties, under international law by employing critical approach to international law (CATIL). Finally, conclusions are drawn from the analysis.

\footnotetext{
${ }^{2}$ Egypt has evaded basin-wide agreements, and seeks to retain the hegemonic status quo. Egypt's refusal to sign the 2010 Nile Basin Cooperative Framework Agreement (CFA) verifies Egypt's reluctance to accept the principle of equitable utilization. Egypt's strategic use of international law to extend its hegemonic posture. See, for example, Joyeeta Gupta (2016), 'The Watercourses Convention, Hydro-hegemony and Transboundary Water Issues, ' The International Spectator, 51:3, 118-131,

${ }^{3}$ The colonial era agreements that provided Egypt with leverage and upper-hand in the Nile politics are the Agreements between colonial powers (the Anglo-Italian protocol of 1891, the 1906 agreement, the 1925 Anglo-Italian agreement, and the 1934 agreement between Britain and Belgium); Agreements between colonial powers and the basin states and between Egypt and Sudan (After their Independence). The 1902 AngloEthiopian agreement, the 1929 agreement between Britain and Egypt, and the 1959 agreement between Egypt and Sudan. Under the 1902 Anglo-Ethiopian Agreement, different arguments on the basis of language and treaty interpretations are pervasive. Ethiopia did not (in 1902) agree not to construct any hydro-project, and it had only agreed not to totally block the Nile waters.

${ }^{4}$ Egypt has never dropped its claim of 'historic', 'acquired' and 'current use' rights over the Nile River. Egypt is negotiating the GERD without dropping such claims that violate the principle of equitable utilization. This longstanding stance clearly reveals hydrohegemony. For a detail understanding of the interface of hydro-hegemony and international law, read Melvin Woodhouse (2008), 'Hydro-hegemony and international water law: grappling with the gaps of power and law', Water Policy, 103-119
} 


\section{The GERD Negotiations: From Unwarranted Encroachment to Coercion}

GERD is Ethiopia's self-funded sovereign project which is expected to provide some 5600 megawatt of energy upon its full operation. ${ }^{5}$ Sudan will clearly benefit from the GERD because it reduces harm from rainy season floods, and as a border dam (to Ethiopia) it is Sudan rather than Ethiopia that would benefit from the dam for stable irrigation. That was why Sudan had at various occasions expressed its neutrality until Egypt's geo-political manoeuvres and hegemony ultimately triumphed over its genuine national interests.

The project, since its announcement on $2^{\text {nd }}$ of April 2011, has attracted negative reaction from Egypt. Understandably, the anxiety came from the hegemonic ego that is nurtured and entrenched by a century old exclusive exploitation of a shared resource. Awkwardly, Egypt's aggressive reaction and Ethiopia's misguided entrance into the entrapment have contributed the GERD to be treated as an international matter of concern as such. ${ }^{6}$

Egypt has perceived GERD as a counterhegemonic advent that could counter its hegemonic control on the Nile River. To block that counterhegemonic resonance, Egypt has established an overt narrative of harm to table its real interest before the diplomatic train. ${ }^{7}$ The power balance between Ethiopia and Egypt before the starting of the GERD was to the favour of Egypt as Egypt was a hydro-hegemon power in the Nile Basin. That status quo has started to crack since Ethiopia launched the GERD project. ${ }^{8}$

Ethiopia's 5 Billon Dollar mega project, has defied Egypt's hydrohegemony and this surprise was a moral avalanche to the country. ${ }^{9}$ That moral

\footnotetext{
${ }^{5} \mathrm{https}$ ://www.webuildgroup.com/en/projects/dams-hydroelectric-plants/grandethiopian-renaissance-dam-project

${ }^{6} \mathrm{http}: / / \mathrm{www}$.meleszenawi.com/ethiopian-pm-meles-zenawi-speech-on-launching-gerdtext-and-videos/

${ }^{7}$ Egypt's narratives on the Nile politics have controlled both the national and international political domain. Nationally, it has characterized the Nile's status as a matter of existential importance and Article 44 of its constitution commits the state to preserving Egypt's "historical rights" to the river.

8 Mohammed Yimer (2015), 'The Nile Hydro Politics; A Historic Power Shift', International Journal of Political Science and Development, Vol. 3(2), pp. 101-107

9 Gashaw Ayferam Endaylalu (2019), 'Counter Hydro Hegemony Mechanisms and Their Roles in the Eastern Nile Basin', International Affairs and Global Strategy. As thoroughly discussed in this paper, GERD, along with other prior strategies, was a right project to righting the past injustice and to counter Egypt's hydro-hegemony.
} 
backlash could have been maintained had Ethiopia not opened its diplomatic gateway for Egypt and Sudan. By inviting Egypt and Sudan to the GERD matter, Ethiopia has attacked its own leverage.

By having its footage in the GERD project, Egypt was able to revive its moral hegemony that was cracked by Ethiopia's announcement of the GERD project. Upon inviting the two downstream states into the GERD discussion, the claim for negotiations became a trap. Ethiopia's initiatives towards cordial relations could have been confined to duly informing the downstream riparians (through trilateral forums of professionals) that the GERD ultimately enhances Ethiopia's efforts and commitment to the basin's environmental preservation that ensures the sustainability of the water course and equitable utilization among all riparians without causing significant harm.

Egypt, once retaking its moral hegemony which was once snatched by Ethiopia's surprise announcement of the GERD, has set another strategy that targets at preserving its hegemony in the Nile Basin. As revealed in the GERD negotiations, Egypt's strategy is to entrap Ethiopia in an agreement that would prohibit the latter from launching future projects over the Blue Nile River.

Ethiopia's imprudent decision to invite Egypt and Sudan to assure common trust between the three countries was an enabler for Egypt's move against Ethiopia's emergence as a counter-hegemonic power. The path-breaking deal for Egypt was signed in March 2015. This declaration (which is merely a framework and not a treaty) has made Egypt and Sudan to speak confidently in their coercive move in the attainment of their plans. They have used this instrument as a shield to cover their coercive strategy. Portraying Ethiopia as a defiant to the Declaration of Principles (DoP) before the international community has helped them to play their coercive game behind the scenes. They have even gone beyond the spirits and contents of the Declaration of Principles.

Indeed, Egypt chose the right time to aggressively use its coercion strategy and it, through its president, made a point in the 2019 UNGA summit. ${ }^{10}$ That was a turning point from silent manoeuvres to open strategy of escalation, internationalization, and securitization of the GERD through the use of pressure and coercion. ${ }^{11}$

\footnotetext{
${ }^{10} \mathrm{https}$ ://semonegna.com/egypts-president-at-unga-speaks-about-nile-river-ethiopiasrenaissance-dam/

${ }^{11}$ The U.S. Treasury Department invited the parties for talks in late October after Egypt's President Abdel Fattah al-Sisi and Ethiopia's Prime Minister Abiy Ahmed met on the sidelines of Russia's Africa summit in Sochi. (https://www.crisisgroup.org/africa/hornafrica/ethiopia/nile-dam-talks-unlocking-dangerous-stalemate )
} 
Ethiopia's injudicious approach in the handling of the GERD paved the entry point for Egypt to promote its agenda of pretending as a 'victim' of prospective harm. The entry point for Egypt's manoeuvres and manipulation started in 2012 when Ethiopia agreed to the establishment of the international panel of experts (IPoE) to review the design and study documents of the GERD project. $^{12}$ Egypt used the forum to reverse the hard-won counterhegemonic project with a view to subjecting the project to its sphere of influence.

Since then, Egypt is vying to extend its hegemonic control over the Nile waters and it is working aggressively towards the possibility of its desired outcome from the GERD negotiations. The GERD negotiations, if completed as per Egypt's desire, would legitimize and make its hegemonic control of the Nile River unchallenged.

Once the IPoE paved the way for Egypt and Sudan to have a say on Ethiopia's unilateral project, subsequent manipulations easily continued. The IPoE released its studies on December 2013 and it recommended further joint studies on the impacts of the GERD. Ethiopia was not hesitant when it agreed to establish the Technical National Committee (TNC) charged with undertaking of further studies in 2014. However, the TNC did not pursue its studies due to disagreements on the process.

Another diplomatic mistake whose impact lingers to this day was committed in 2015 when the leaders of three governments signed the Declaration of Principles (DoP). ${ }^{13}$ The DoP clearly brought a windfall opportunity to Egypt and Sudan to use it as a playing card for the internationalization and escalation of the GERD dispute, even if the careful interpretation of the principles do not justify the various claims of the lower riparian states. Egypt and Sudan invoke the DoP as a legal ground for the GERD dispute in order to internationalize the issue. Without this instrument Egypt and Sudan could not have been able to capture such international attention over the GERD issue. ${ }^{14}$ The Blue Nile floods and the harm caused to Sudan (during the rainy season of 2021, even after the second impoundment

${ }^{12}$ GERD is proclaimed as a flagship project. If that is the case, GERD should not have been subject of international negotiation as negotiating a flag is an absurd diplomacy.

${ }^{13}$ Declaration of Principles, Khartoum, 2015

${ }^{14}$ Egypt invokes this instrument whenever it appeals for the sealing of an agreement on the filling and operation of the GERD. Egypt incorrectly submitted this instrument to support its allegation that Ethiopia's unilateral filling, without a deal, would violate the latter's duty to conclude an agreement as enshrined under Article 5 of the DoP. By doing so it has attracted the attention of the international community. 
of the first phase filling of the GERD) shows that the dam would not cause significant harm to downstream riparian states. We can imagine how grave the floods and harm could have been to Sudan in the absence of the GERD.

The diplomatic red-line was crossed in November 2019 when Ethiopia accepted the intervention of the United States and the World Bank. This turn, in the history of GERD negotiations could be marked as the opening of diplomatic Pandora box. ${ }^{15}$

Egypt unilaterally invited the USA and the World Bank (WB) to intervene in the GERD negotiations, and it was apparent that the intervening parties exerted pressure on Ethiopia. Given Ethiopia's heavy dependence on those two partners for aid and loans, Egypt indeed chose the right partners for its escalation and internationalization strategies. Ethiopia's refusal to sign the Washington Document and its consistent demand for an African Union-led process was followed by reprisal from the United States.

It was during this critical juncture that a provocative abrupt statement was made by the then US President, Donald J Trump ${ }^{16}$ who (in October 2020) said that Egypt will 'blow up' the dam as if there can be victors in bombing dams. It should have been clear to President Trump that such acts would merely lead to reciprocity and downstream destruction through floods and water flow diversions.

Negotiations are being carried out under the African Union's de facto mediation role but the pressure from Egypt and Sudan is still mounting. ${ }^{17}$ At the time of the writing of this comment, the GERD negotiations are stalled since the disagreement of the negotiating parties on the modalities of the negotiation in their latest meeting in DRC, Kinshasa. ${ }^{18}$ Egypt and Sudan were

15 https://home.treasury.gov/news/secretary-statements-remarks/statement-by-thesecretary-of-the-treasury-on-the-grand-ethiopian-renaissance-dam. See also http://www.xinhuanet.com/english/2020-03/05/c_138844013.htm

${ }^{16}$ Since 28 February 2020, Negotiations before the sole observation of the USA and WB came to an end. The tension escalated since then. Egypt and Sudan enhanced their coercive diplomacy since Ethiopia's rejection to the draft document jointly drafted by the USA and WB experts.

${ }^{17}$ A clear message of threat to use force has been forwarded from the two countries. Sudan had claimed neutrality at some intervals while on the contrary it has transgressed and occupied some 40-50 kms of Ethiopian territory.

${ }^{18}$ Egypt and Sudan have proposed the increased role of the observers and they proposed mediation before a quartet [The African Union, European Union, United States and the United Nations]. Ethiopia rejects the increased role of the observers and it sticks to the AU-led process under the auspices of the African Union. 
threating Ethiopia with coercion to induce a deal on the filling and operation of the GERD.

\section{Coercion as a Driving Force in the GERD Negotiations: Adducing Evidence}

Coercion could be defined as the act, process, or power of compelling through the use of express or implied threats of violence or reprisal or other intimidating behaviour that puts a state in a fear of the consequences. It is used to compel that state, a coerced one, to act against its sovereign will. ${ }^{19}$ It may assume various forms that have in common the will of a state to force another state into taking a particular action. ${ }^{20}$

The use of coercive power, by the coercing state, to compel the coerced state to accept a deal or to engage in a commitment without its will is a purposeful and intentional act of the coercing state. For coercion to exist an outcome from that coercion is not necessarily required because the coercing state need not be successful in achieving its expectations and goals. What is very important is the exertion of a compelling force by the coercing state with full knowledge and intent.

All forms of coercion, as the strategy of compelling a state to accept a deal unwillingly, are manifested in the GERD Negotiations. There was military coercion (in the form of threats) through the repeated warnings of Egypt to use all necessary means to protect Egypt's interest over the Nile Water. ${ }^{21}$ Beyond the threats to use force, Egypt is engaged in doubling its military capabilities from year to year. The recent joint military pact signed between

${ }^{19}$ Cambridge Dictionary defines coercion as the use of force to persuade someone to do something that they are unwilling to do. Black's Law defines coercion as compulsion, constraint, compelling by force or arms.

${ }^{20}$ Natalino Ronzitti , 'Sanctions as Instruments of Coercive Diplomacy: An International Law Perspective' in Natalino Ronzitti (eds), Coercive Diplomacy, Sanctions and International Law (Brill Nijhoff, 2016), p. 2

${ }^{21}$ The warning of using all necessary means to protect 'Egypt's Nile Waters Rights' is a century old mantra of Egypt's leaders. The warning has survived for centuries. But compared to the usual rhetoric of water war, the recent rhetoric has a sort of imminence given Ethiopia's current efforts to utilize its fair share from the Nile waters.

https://www.haaretz.com/middle-east-news/egypt/egypt-vows-to-use-all-means-todefend-nile-interests-after-ethiopia-skips-talks-1.8600505 
Egypt and Sudan is the latest showcase of a military coercion against Ethiopia. ${ }^{22}$

One may wonder whether the recent threats of war expressed either through 'all necessary means' or the joint military preparations can put Ethiopia under a military coercion. Such military threats are clearly short sighted because destabilized Ethiopia through direct threats or proxy civil wars would merely enhance poverty, over-dependence of smallholder farmers on the water basin catchment, encroachments to sloppy water basin catchment areas, enhanced erosion and aggravated siltation thereby eventually causing the 'end' of the Blue Nile water course.

In the short run, the existing threats of war and joint military preparations of Egypt and Sudan, coupled with the change in the internal and external political and geo-political dynamics, may seem to have a coercive effect on Ethiopia's position in the GERD negotiations. The issue here is not whether Ethiopia would kneel down to the pressure of such threats or not. The presence of military coercion in this case should be evaluated independent of its effect or outcome.

The evaluation relates to the intentional use of such negotiation strategies by Egypt and Sudan. Undoubtedly, they are using such threats purposefully and intentionally to coerce Ethiopia so as to achieve their goals in the GERD negotiations. There is no other country than Ethiopia where their military showcases, preparations and threats is being addressed. In fact, Egypt and Sudan have never make it in secret; and they are rather making it publicly. For example, the designation of the joint military training as "Protectors of the Nile" was clearly provocative and it targeted at intimidating Ethiopia as it unequivocally revealed the purposes of the joint preparations. ${ }^{23}$

With regard to economic and political coercion, these tools are simultaneously used by Egypt and its co-opting global allies. The economic coercion is dependent on the political/ geo-political coercion. The United States is an accomplice in the exertion of geo-political and economic coercion. As an observer that was singlehandedly elected by Egypt in November 2019,

${ }^{22}$ The joint military pact and training between the two countries is not something that can be ignored. Given the shift in Sudanese position and its aggression on Ethiopia's border, there is tension in the region.

${ }^{23}$ Joint trainings between Egypt and Sudan reveal security threat in the sub-region. "The Egyptian Armed Forces arrived in Sudan on Thursday to conduct a joint military training called 'Protectors of the Nile', amid the ongoing Grand Ethiopian Renaissance Dam (GERD) crisis.” (See, https://www.egyptindependent.com/egyptian-sudanesearmed-forces-conduct-joint-military-exercise-in-sudan/ ) 
the United States has indeed put both political and economic coercion on Ethiopia throughout the 2020 rounds of GERD negotiations.

Egypt, as a planner of the strategy, was sure that those global powers could exert their political and economic pressure on Ethiopia towards any deal brokered by them. Negotiations, under their observation, were proceeding as planned by Egypt. The United States had coerced Ethiopia's negotiating team with possible consequences if they refuse to agree and the then-president had even threatened to give a phone call to Ethiopia's Prime Minister in the middle of the negotiation ${ }^{24}$ unduly assuming that the leadership could have different views over the issue.

The pressure exerted on Ethiopia in the process of the negotiations have unequivocally manifested the political and diplomatic coercion that was aimed at compelling Ethiopia to agree with the terms and conditions dictated by the US and the World Bank. These facts were ultimately reaffirmed by the 28 February 2020 statement of US Treasury of State which acrimoniously threatened Ethiopia not to proceed with the filling of the GERD before striking a deal with Egypt and Sudan. The statement called upon Ethiopia to sign the Washington Draft Agreement sooner than later. Generations of international water law students will draw lots of lessons from the draft that was meant to confer veto powers to Egypt in all future water use projects of Ethiopia including the quantified release from Ethiopia's dam during dry seasons resulting from shortages of seasonal rainfalls.

Given the factual inequality of Ethiopia and the USA, powerful statement from US President apparently creates pressure on Ethiopia. The existence of coercion cannot be relinquished merely because the coerced party did not submit to it. Pursuant to its warning, the US has cut some 130 Million US Dollars in development aid to Ethiopia. This was a final stage of economic coercion. It was in addition to such aid cut measure that incitement for a threat of military attack came from President Trump's threats. ${ }^{25}$

Egypt's propaganda and diplomacy has indeed deceived the international community and powerful global actors that were induced to perceive that conclusion of an agreement is mandatory. Accordingly, various powerful global actors including the US and EU had kept on calling upon Ethiopia to agree with Egypt and Sudan to resolve the GERD dispute. Intentionally or negligently, these partners did not pay due attention to the bad faith and

\footnotetext{
${ }^{24}$ Author's discussion with an anonymous insider to the negotiating team.

${ }^{25}$ Although all forms of coercion exerted from the US and the World Bank did not compel Ethiopia to sign a deal (the Washington Draft or newly negotiated one), the pressures have kept Ethiopia to stay in the GERD negotiations.
} 
coercive strategy of Egypt that is reluctant against any win-win solution over the GERD dispute based on equitable utilization.

Unlike the jurisprudence on unilateral development projects, GERD is placed on the top list agenda of powerful global actors as a matter of international concern. Realizing such a seizure, Egypt and Sudan had continued to threaten Ethiopia with military coercion to force the latter to sign a GERD deal before the filling of the second phase of the first stage impoundment of the Blue Nile water. ${ }^{26}$ However, Ethiopia has insisted on asserting its rights for equitable utilization of its resources and the GERD negotiations are still underway in the context of political, economic, and military coercion. ${ }^{27}$ Whether such coercion is permissible under international law will be discussed in the next section.

\section{The Legal Contours of Coercion}

Negotiation is one of the key instruments in inter-state relationships. Leverage and power-balance are the best tools to secure interest in the inter-state negotiations. Geo-strategic location, ideational and material or military power can serve States to have a leverage and to take advantage over counterparts. All such strategies are acceptable to the extent that they do not subdue States under forceful coercion. Hence, coercive diplomacy employs military, economic and political forces or compulsion to arm-twist States to succumb their vital national interests.

The threat or use of force is prohibited under the UN Charter. ${ }^{28}$ What does force or coercion mean? Does it constitute all forms of coercive power? ${ }^{29}$ What type of force or coercion is prohibited under the UN Charter? Answering these questions is indispensable for the themes in this comment.

${ }^{26}$ Egypt has been using coercion to compel its counterparts to sign a deal over the Nile Waters. For example, the 1959 'Full Utilization of the Nile Waters' Agreement between Egypt and Sudan was signed after Egypt supported an insurrection in Sudan and removed the Sudanese leader who was reluctant to sign the deal.

${ }^{27}$ A reader who might deny the existence of coercion in the GERD negotiations, can still consider the GERD negotiations illegitimate because through coercive diplomacy, Egypt and Sudan, along with the United States, have interfered in the domestic matter of Ethiopia. By doing so, they have violated Article 2(7) of the UN Charter and UNGA resolution 2625 (whose contents are believed to have attained the customary international law normative status).

${ }^{28}$ The prohibition of the Use of Force or Jus Ad bellum dates back to the 1929 the KelloggBriand Pact (AKA Paris Pact). The UN Charter merely reaffirms the pre-existing norm of international law.

${ }^{29}$ Coercion and force can be used interchangeably. 
There are two approaches of understanding the prohibition of the threat or use force. The restrictive approach considers Article 2(4) of the UN Charter as a prohibition of the threat or use of armed (military) force. According to this view, States are only prohibited to use military force except in cases of self-defense and collective self-defense. All other forms of coercion or force less than armed force are not prohibited.

According to this view, States who purposefully use other forms of coercive power in their international relationships cannot be held responsible for the use of force unless the coercion falls under resort to the threat or use of military force against other states. This understanding has wide recognition in the International Court of Justice (ICJ) jurisprudence and the Vienna Convention on the Law of Treaties (VCLT). Article 52 of VCLT clearly forbids states not to resort to threat or use force in their treaty making. A treaty concluded as a result of threat or use force is void. ${ }^{30}$

The expansive interpretation tends to uphold all forms of coercive powers as prohibited under international law. This interpretation uses a purposive and holistic understanding of the UN Charter. It construes that all forms of coercion, economic, political and military, are prohibited both in the UN Charter and customary international law. According to this perspective, unless Article 2(4) of the UN Charter incorporates all forms of coercion, it cannot be compatible with the overarching purposes of the UN and this will be in contradiction with other principles of the charter.

Member states of the United Nations have reaffirmed equal rights of nations -large and small- and have agreed to unite their strength to maintain international peace and security. These aims and resolutions stated in the preamble indicate the rationale for the establishment of the UN. It is on the basis of these motives that the operative parts of the UN Charter are engraved.

Article 1 states the purposes of the UN that are aligned to the preceding aims embodied in the preamble. A close reading of Article 1(1) of the Charter shows that coercion, in any form, negates the maintenance of international peace and security; and coercion, in all forms, can be a threat to the peace; it can also be breach of the peace. Hence, the use of psychological, diplomatic, economic and military coercion violates the equal rights of nations large and small enshrined under the UN Charter.

The use of coercion in the process of settlement of international disputes contravenes the second purpose of the UN, the development of friendly relations among nations based on respect for the principle of equal Rights.

${ }^{30}$ Vienna Convention on the Law of Treaties, 1969 
Apparently, the use of economic and diplomatic pressure by a disputing party against the other party in the course of negotiations obstructs friendly relations. It also violates the principle of equal rights and universal peace.

The use of all forms of coercion, does not conform to the third principle of the UN Charter. Coercion in the settlement of international disputes will be a stumbling block to achieve international co-operation. It cannot solve international problems. Nor will it promote and encourage respect for human rights and fundamental freedoms. It could rather fuel the tension between the coercing and coerced states. Moreover, the use of coercion will disrupt harmonious relationship of nations and it will affect their common determination to attain their common ends thereby infringing the fourth purpose of the UN Charter.

As stated under the introductory sentence of Article 2, the UN and its members are obliged to pursue the purposes of the UN. In light of purposes, coercion is clearly against the principles of the UN. Coercion clearly violates the first principle of the $\mathrm{UN}$, the principle of the sovereign equality of all UN Members. By employing coercion against the full and free consent of the coerced state, the coercing state is acting in violation of the cardinal principle of the UN, i.e., the sovereign equality of UN members. If, for example, a state accepts a deal by the coerced state without its free consent, the sovereign equality between the coerced and coercing state is violated.

Moreover, coercion contravenes the duty of good faith among UN member states members in the fulfilment of their obligations under the UN Charter. Coercion further violates the third principle of the UN Charter which requires member states to settle their international disputes by peaceful means in such a manner that international peace and security, and justice, are not endangered. The use of coercion, irrespective of its forms, can endanger international justice, peace and security.

An argument may be raised that all forms of coercion will not have equal impact in endangering justice, international peace and security. Although this line of argument may seem plausible, the repeated use of diplomatic and economic coercion in dispute settlement and negotiations would endanger international peace and security, and justice. Moreover, the relationship between the coerced and coercing state will not be peaceful and just. Even worse, the use of diplomatic and economic coercion in the process of dispute settlement may lead to a military coercion in the forms of threat or use of force.

Hence, allowing other forms of coercion is pushing the coercing states half-way to the threat or use of force. The specific use of military coercion 
contravenes the fourth principle of the UN that prohibits the threat or use of force in international relations.

Under Article 33, (Chapter VI, pacific settlement of international disputes), the parties to any dispute shall first of all, seek a solution by negotiation, enquiry, mediation, conciliation, arbitration, judicial settlement, or other peaceful means of their own choice. All means listed under Article 33 of the Charter require the participation of disputing parties in their full and free consent.

Hence, the fact that the negotiating states have relentlessly used all forms of coercion in the GERD Negotiations to bow Ethiopia down violates the purposes and principles of the UN Charter. GERD, as an essential domestic matter of Ethiopia, should not have been subjected for an international diplomatic discourse and series of pressures. Thus, economic, political and military coercion in the GERD negotiations is a blatant violation of the purposes and principles of the UN Charter that are enshrined in articles 1 and 2; and it violates Ethiopia's sovereignty and political independence that is guaranteed and assured by the UN Charter and customary international law. ${ }^{31}$

Both lines of interpretations, i.e. the restrictive and expansive approaches in the definition of coercion, correspond with the static and Evolutive approaches in treaty interpretation. The static approach in treaty interpretation is in support of the restrictive understanding of the prohibition on the threat or use force whereas the Evolutive treaty interpretation supports the expansive understanding of Article 2(4) of the UN Charter. Evolutive treaty interpretation calls for the taking into account of international realties and dynamics during the application of a treaty that was concluded several years ago.

Irrespective of its drafting history, the VCLT recognizes only the use of military coercion as a ground of invalidation. Its legislative history uncovers that there was a need and call for the inclusion of political and economic coercion as grounds of treaty invalidation. ${ }^{32}$ In order to accommodate the interests of states who had requested the inclusion of all forms of coercion as grounds of treaty invalidation, an alternative declaration was made a

${ }^{31}$ Notwithstanding this line of argument, there is a growing move on 'State's Right to be Free From Economic Coercion'. See Antonios Tzanakopoulos (2015), 'The Right to be Free from Economic Coercion', Cambridge Journal of International and Comparative Law, Vol. 4, pp. 616-633.

${ }^{32}$ Charles E. Partridge, JR (1971), 'Political and Economic Coercion: Within the Ambit of Article 52 of the Vienna Convention on the Law of Treaties?' International Lawyer, Vol. 5, No. 4, 755-769 
supplement to Article 52 of the VCLT. The declaration on the prohibition of military, political or economic coercion in the conclusion of treaties reads:-

This declaration 'solemnly condemns the threat or use of pressure in any form, whether military, political, or economic, by any State, in order to coerce another State to perform any act relating to the conclusion of a treaty in violation of the principles of the sovereign equality of States and freedom of consent.' 33

Political coercion may correspond to the principle of non-intervention in the internal and external affairs of States. ICJ has affirmed that conduct involving a manifestation of a policy of force constitutes a violation of both Article 2(4) of the UN Charter and the Principle of non-intervention. ${ }^{34}$

Using an Evolutive treaty interpretation and expansive understanding of the use of coercion, Article 52 of the VCLT should be interpreted in a way that can prohibit the use of political and economic coercion in treaty negotiations and conclusions. Such an expansive and broader interpretation is

${ }^{33}$ The Declaration was introduced to "supplement" Article 52 of the VCLT. It states the principle that not only military but also economic and political pressure, or the threat thereof, may not be used to coerce a State to conclude a treaty in violation of the sovereign equality of States and freedom of consent. Full picture can be noted on "M.E. Villiger, The commentary 1969 Vienna Convention on the Law of Treaties] The constitutive instrument of the OAS contains a provision outlawing economic coercion (Art 20); the UN General Assembly Declaration on Friendly Relations (2625-xxv), the UNGA Resolution 42/173 on Economic Measures as a Means of Political and Economic Coercion against Developing Countries of 1987 and the Helsinki Final Act of 1975. See, Natalino Ronzitti, Sanctions as Instruments of Coercive Diplomacy: An International Law Perspective in Natalino Ronzitti (eds), Coercive Diplomacy, Sanctions and International Law (Brill Nijhoff, 2016), pp. 1-3

${ }^{34}$ Id., p. 4. (The cases are Corfu Channel (United Kingdom of Great Britain and Northern Ireland v. Albania), Judgment of 9 April 1949, ICJ Reports 1949, p. 35.; Military and Paramilitary Activities in and against Nicaragua (Nicaragua v. United States of America), Judgment of 27 June 1986, ICJ Reports 1986, p. 106.; Case Concerning Armed Activities Case in the Territory of the Congo (Democratic Republic of Congo v. Uganda), Judgment of 19 December 2005ICJ Reports 2005, p. 227, para. 163). Resolutions 2131 (xx), 2625 (xxv) and 36/103 which are dedicated to the principle of non-intervention. UNGA Res. 3171 (xxviii) on Permanent Sovereignty over National Resources, 17 December 1973, U.N. Doc. A/RES/3171, which emphasize the duty to refrain from military, political, economic or any other form of coercion aimed against the territorial integrity of any State and the exercise of its national jurisdiction. In addition Article 32 of Resolution 3281 (xxix) on the Charter of Economic Rights and Duties of States and paragraphs 7-8 (Ibid). Article 4 (9) of the Constitutive Act of the African Union establishes the "non-interference by any member State in the internal affairs of another State". 
steadily gaining acceptance, and it should indeed be the prevailing ${ }^{35}$ mode of interpretation.

Hence, the holistic reading of the purposes and principles of the UN leads to the conclusion that the UN Charter prohibits all forms of coercion in the process of pacific settlement of international disputes. This conclusion, in turn, can dictate the revision of Article 52 of the VCLT to include economic and political coercion as grounds of invalidation. Meanwhile, customary international law can be used as a source to make all forms of coercion unlawful.

\section{The Duty to Conclude Treaty: With or Without Coercion}

International law does not impose the duty of negotiation nor conclusion of an agreement or treaty. It generally sets an obligation to settle international disputes through peaceful means. ${ }^{36}$ The choice relating to the particular scheme for peaceful settlement of disputes is at the discretion of disputing states. ${ }^{37}$ Likewise, concluding an agreement or a treaty is based on the free will of a State, and this manifests state sovereignty. ${ }^{38}$

The jurisprudence of international adjudication bodies does not render unilateral projects of transboundary watercourses subject to bilateral or multilateral negotiations. ICJ's jurisprudence on the duty to negotiate makes unilateral projects, such as the GERD, outside the remit of States' duty to negotiate. The North Sea Continental Shelf, Fisheries Jurisdiction and Access to the Pacific Ocean cases before the ICJ can shed light on the duty to negotiate and conclusion of agreement.

In the Continental Shelf case, the ICJ held that the States have the duty to negotiate when the dispute is on the subject matter of delimitation of a boundary. ${ }^{39}$ The dispute was specifically on the delimitation of boundary on a continental shelf. In the Fisheries Jurisdiction case, ICJ set the precedent on the duty to negotiate when the dispute incorporates a determination of the rights of each party in the dispute. ${ }^{40}$ In ICJ's (2018) Judgment on the Merits in Obligation to Negotiate Access to the Pacific Ocean (Bolivia v. Chile),

${ }^{35}$ O Corten, 'Article 52 - Convention of 1969' in O Corten and P Klein (eds), The Vienna Conventions on the Law of Treaties -A Commentary (OUP 2011) 1201, 1205-1211.

${ }^{36}$ Handbook on the Peaceful Settlement of Disputes between States (Office of Legal Affairs Codification Division, UN, 1992)

${ }^{37}$ Id, p.7

${ }^{38}$ VCLT, Art 6

${ }^{39} \mathrm{https}$ //www.icj-cij.org/en/case/52, Para 85

${ }^{40}$ https://www.icj-cij.org/en/case/55 
Bolivia requested the Court to adjudge and declare that "Chile has the obligation to negotiate with Bolivia in order to reach agreement granting Bolivia a fully sovereign access to the Pacific Ocean", and that "Chile breached such an alleged obligation and should be directed to perform it."41 The court held that:

In international law, the existence of an obligation to negotiate has to be ascertained in the same way as that of any other legal obligation. Negotiation is part of the usual practice of States in their bilateral and multilateral relations. However, the fact that a given issue is negotiated at a given time is not sufficient to give rise to an obligation to negotiate. In particular, for there to be an obligation to negotiate on the basis of an agreement, the terms used by the parties, the subject-matter and the conditions of the negotiations must demonstrate an intention of the parties to be legally bound. This intention, in the absence of express terms indicating the existence of a legal commitment, may be established on the basis of an objective examination of all the evidence. ${ }^{42}$

The court further held that there was not such obligation contained in Chile's statements or unilateral acts. ${ }^{43}$ It did not find acquiescence by Chile or estoppel against Chile. ${ }^{44}$ The Court finally declared that "there was no such thing in general international law as an obligation arising from a State's legitimate expectations." 45 Nor does the specific obligation to negotiate sovereign access exist under the UN Charter or the Charter of the Organization of the American States. ${ }^{46}$

The three cases show that the duties to negotiate and conclusion of treaty do not apply to every international subject matter. These precedents, coupled with precedents on international water disputes, underscore the nonnegotiability of unilateral projects over transboundary watercourses; and such projects do not entail the duty to conclude an agreement. ${ }^{47}$ Furthermore, it is

${ }^{41}$ The Merits in Obligation to Negotiate Access to the Pacific Ocean (Bolivia v. Chile), ICJ, para. 11.

${ }^{42}$ Id., para 91

${ }^{43}$ Id., paras, 140-148

${ }^{44}$ Id., paras. 149-162

${ }^{45}$ Id., para. 162

46 Id., paras. 163-174

${ }^{47}$ Precedents of different international tribunals on the settlement of disputes emanating from projects built on transboundary watercourses do not subject a unilateral dam to international negotiation. Some of the well-known cases in this regard are: 1.The 1957 Lake Lanoux Arbitration (France v. Spain); 2. The 1997 Case concerning the 
to be noted that a deal on a single unilateral project of a dam cannot decide the present and future rights of co-riparian states on a transboundary watercourse. The business of determining the rights of co-riparian states in a transboundary watercourse calls for a different approach such as basin-wide water sharing comprehensive treaty among all riparians within the Nile Basin Cooperative Framework Agreement (CFA).

The next question will thus be the aptness of GERD's subjection for trilateral negotiations. In an unhistorical move, GERD is the first project that has ever been subjected to trilateral negotiation. The norms and practices of international watercourses governance do not have such practices and the only expectation and in fact recommendation of the regime of international watercourses governance is to set a basin-wide legal and institutional arrangement that could be tasked with the governance of a given watercourse based on the principles of equitable utilization and causing no significant harm among co-riparians.

In the absence of basin wide institutional and legal venues, every riparian country has the legitimate right to build and operate unilateral projects on the watercourse. Other co-riparians can have the right to bring a legal action only after the dam owner completes and operates its project and if significant harm arises from the operation of the project. The dam owner has the duty not to cause significant harm against the water uses of other riparians. However, the pressure on GERD (highlighted above), is totally different from this conventional regime of international watercourses governance. ${ }^{48}$

Gabcikovo-Nagymoros Project (Hungary v. Slovakia); 3. The 2006 Case concerning Pulp Mills on the River Uruguay (Argentina v. Uruguay), Request for the Indication of Provisional Measures. Three of these disputes were dependent on the prior agreements between the disputing parties on the utilization of their shared waters. In all cases, the ICJ and the Arbitration tribunal were requested to interpret and apply the treaties signed between the disputing parties before and during the launching of projects. In Gabcikovo-Nagymoros, a dispute arose from a joint project while the Lake Lanoux and Pulp Mills Cases were unilateral projects. Compared with these cases, the subjection of GERD to a trilateral negotiation is unique and absurd. The absurdity comes from two facts, first, GERD is not a joint project of the three negotiating States. Second, there is no prior trilateral or basin-wide agreement that can trigger the GERD negotiations before the launching of the GERD project. It is to be noted that the 2015 Declaration of Principles, does not entail a mandatory duty of negotiation on Ethiopia. 48 Supra note 47. 


\section{Concluding Remarks}

GERD has become a subject matter of discussion and negotiation between the dam owner and other riparians. The subjection of GERD for such premature trilateral negotiations was the result of the manipulative pressures of Egypt and Ethiopia's initial diplomatic imprudence. ${ }^{49}$ GERD was not ripe for such negotiations during both periods mentioned earlier, i.e., 2012 or 2021. In light of the issues discussed in the preceding sections, Ethiopia does not have a legal obligation to negotiate and conclude an agreement on the filling and operation of the GERD with Egypt and Sudan. This conclusion remains valid even with or without proving coercion in the GERD negotiations.

Four points need due attention. First, the GERD negotiations have-since November 2019- encountered all forms of coercion that are, arguably, illegal under international law. Second, Ethiopia has the right to withdraw from the negotiation that is entwined with series of coercion by invoking the UN Charter and law of treaty. Third, Ethiopia is not under a legal obligation, to conclude any deal over the filling and operation of GERD. Therefore, any agreement that could be concluded by coercion would be of no legal effect.

The fourth issue relates to the way forward. The most appropriate means of safeguarding the balance between the principle of equitable utilization and the principle of causing no significant harm is a basin-wide water governance treaty. This requires Egypt's readiness to detach itself from its 'historic rights' narratives -based on colonial 'treaties'- by duly recognizing the apparent fundamental change of circumstances (rebus sic stantibus) in view of the magnitude of environmental degradation in the basin accompanied by the steadily growing population whose livelihood is clearly dependent on the watercourse.

49 Ethiopian government's justifications for subjecting the GERD for an international negotiation was clearly unpersuasive. The justifications of 'confidence building' and 'regional cooperation' were unconvincing because they could have ended up in compromising sovereignty. 


\section{Cited References}

Anghie, Antony (2005). Imperialism, Sovereignty and the Making of International Law (Cambridge University Press,)

Gashaw Ayferam Endaylalu (2019). 'Counter Hydro Hegemony Mechanisms and Their Roles in the Eastern Nile Basin', International Affairs and Global Strategy

Gupta, Joyeeta (2016). 'The Watercourses Convention, Hydro-hegemony and Transboundary Water Issues, 'The International Spectator

Mohammed Yimer (2015). 'The Nile Hydro Politics; A Historic Power Shift', International Journal of Political Science and Development

Natalino Ronzitti (eds), Coercive Diplomacy, Sanctions and International Law (Brill Nijhoff, 2016

$\mathrm{O}$ Corten and P Klein (eds), The Vienna Conventions on the Law of Treaties -A Commentary (OUP 2011)

Tzanakopoulos, Antonios (2015). "The Right to Be Free from Economic Coercion", Cambridge Journal of International and Comparative Law

Woodhouse, Melvin (2008). 'Hydro-hegemony and international water law: grappling with the gaps of power and law', Water Policy 